\title{
QISHASH DAN MAQASHID AL-SYARIAH (Analisis Pemikiran asy-Syathibi dalam Kitab Al-Muwafaqat)
}

\begin{abstract}
AHMAD RAJAFI ${ }^{\square}$
ABSTRAK

Qishash merupakan praktek hukum yang ada pra-Islam dan dimodifikasi pada masa Islam. Namun, di zaman modern ini muncul aspirasi penolakan terhadap hukum qishash dengan mengatas- namakan hak asasi manusia. Bahkan di kalangan umat Islam sendiri juga terjadi penolakan tersebut dengan alasan bahwa qishash telah melanggar maqashid al-syari'ah, yakni hifzh al-nafs (menjaga jiwa). Oleh karena itu melalui tulisan ini, penulis mencoba menelaah secara mendalam permasalahan qishash ini dengan pendekatan maqashid al-syari'ah yang terangkum secara detail di dalam kitab Al-Muwafaqat karya al-Syathibi.
\end{abstract}

Kata Kunci: Qishash, Hak Asasi Manusia, Maqashid al-Syari'ah

\section{A. Pendahuluan.}

Pada tahun 1944 diadakan Konferensi Buruh Internasional di Philadelphia yang kemudian menghasilkan "Deklarasi Philadelphia". Isi dari konferensi tersebut tentang kebutuhan penting untuk menciptakan perdamaian dunia berdasarkan keadilan sosial dan perlindungan seluruh manusia, apa pun ras, kepercayaan atau jenis kelaminnya, memiliki hak untuk mengejar perkembangan material dan kesempatan yang sama. Semua hak tersebut setelah Perang Dunia II (setelah Hitler memusnahkan berjuta-juta manusia) dijadikan dasar pemikiran untuk menjadi embrio rumusan Hak Asasi Manusia (HAM) yang bersifat universal sebagaimana dalam The Universal Declaration of Human Rights PBB tahun 1948. Akibat dikeluarkannya piagam HAM secara

Dosen STAIN Manado.

Abdul Rozak dkk (ed), Pendidikan Kewargaan Civic Educatioan: Demokrasi 
umum oleh PBB ini, maka hampir seluruh dunia mendukung isi pia- gam ini dan semakin banyak pula dari negara-negara lain yang ikut menjadi anggota PBB, termasuk Indonesia.

Menurut Teaching Human Rights yang diterbitkan oleh PBB tersebut, Hak Asasi Manusia adalah hak-hak yang melekat pada diri setiap manusia, yang tanpanya manusia mustahil dapat hidup sebagai manusia. Hak hidup misalnya adalah klaim untuk memperoleh dan melakukan segala sesuatu yang dapat membuat seseorang tetap hidup, karena tanpa hak tersebut eksistensinya sebagai manusia akan hilang. Berdasarkan penjelasan ini, pada perkembangannya piagam Hak Asasi Manusia (HAM) yang diterbitkan oleh PBB ini seolah-olah menjadi legalitas sekelompok orang untuk menjatuhkan suatu hukum yang sudah berlaku baik tertulis maupun tidak dari segala macam bentuk pidana pada suatu negara.

Tindak pidana dalam Ilmu Hukum Pidana merupakan bagian yang paling pokok dan sangat penting. Rumusan atau definisi tentang tindak pidana tersebut telah banyak diciptakan oleh para sarjana hukum pidana, dan di samping adanya persamaan, terdapat juga perbedaannya. Prof Moeljatno, S.H telah memakai istilah perbuatan pidana yang dirumuskan sebagai perbuatan yang oleh aturan hu- kum pidana dilarang dan diancam dengan pidana, barangsiapa yang melanggar larangan tersebut. Berdasarkan penjelasan ini, menurut wujud atau sifatnya, perbuatan-perbuatan pidana ini adalah perbuatan-perbuatan yang melawan hukum. Perbuatan-perbuatan ini juga merugikan masyarakat, dalam arti bertentangan dengan atau menghambat terlaksananya tata dalam pergaulan masyarakat yang dianggap baik dan adil. Dan dapat ditarik kesimpulan bahwa suatu perbuatan akan menjadi suatu tindak pidana apabila perbuatan itu melawan hukum, merugikan masyarakat, dilarang oleh aturan pidana, pelakunya diancam dengan pidana.

Poin pertama dan kedua menunjukkan sifat perbuatan, sedangkan

Hak Asasi Manusia dan Masyarakat Madani, ICCE UIN Syarif Hidayatullah, Jakarta, 2003, hlm. 204.

A Ubaedillah dkk, Demokrasi Hak Asasi Manusia dan Masyarakat Madani, ICCE UIN Syarif Hadayatulah, Jakarta, 2006, hlm. 252.

Moeljatno, Azas-Azas Hukum Pidana, tp, Yogyakarta, 1980, hlm. 1. 
yang memastikan perbuatan itu menjadi suatu tindak pidana adalah poin tiga dan empat. Adapaun kejahatan terhadap jiwa seseorang di atur di dalam BAB XIX Buku II KUHP. Bentuk yang pokok dari keja- hatan ini adalah pembunuhan (doodslag) yakni menghilangkan jiwa seseorang. Kejahatan terhadap jiwa seseorang mempunyai hubungan erat dengan kejahatan terhadap badan atau tubuh seseorang. Kejahatan terhadap badan itu dapat juga menimbulkan akibat hilangnya jiwa seseorang, meskipun akibat ini tidak dikehendaki, sedangkan keja- hatan terhadap jiwa seseorang mempunyai kehendak hilangnya jiwa seseorang.

Pada kejahatan terhadap jiwa seseorang menimbulkan akibat mati. Akibat matinya seseorang ini dilarang dan diancam dengan hukuman oleh undang-undang. Kejahatan terhadap jiwa merupakan kejahatan yang bersifat materiil, di mana akibatnya yang dilarang dan diancam dengan hukuman oleh undang-undang (tindak pidana materiil). Da- lam praktek kejahatan terhadap jiwa ini meliputi jumlah yang besar setelah kejahatan terhadap harta benda. Oleh sebab itu pada Pasal 338 KUHP Buku II Titel XIX disebutkan, barangsiapa yang dengan sengaja menghilangkan jiwa orang, karena pembunuhan biasa, digan- jar dengan hukuman penjara selama-lamanya lima belas tahun. (CP. 295, 299 v).

Adapun tujuan hukuman dalam hukum pidana umum di Indo- nesia ialah bahwa hukum pidana tidak berisi norma-norma baru, ti- dak meletakkan sebuah kewajiban yang belum dikenal sebelumnya, dan dengan demikian hukum pidana itu tidak melahirkan ketentuanketentuan yang harus dijadikan pedoman di dalam hidup pergaulan, karena hukum pidana merupakan "hukum sanksi". Artinya, hukum pidana itu diterapkan untuk memberikan sanksi atau hukuman kepada mereka yang telah melakukan suatu tindak pidana.

Akan tetapi kenyataan di lapangan adalah meskipun hukum pidana umum ini diterapkan dan dengan mengatasnamakan hak asasi manusia, kejahatan terhadap manusia dengan menghilangkan nyawa

Dali Mutiara Djaksa Kepala Jakarta, Kitab Undang-Undang Hukum Pidana Re- publik Indonesia, Cet. IV, Suar, Djakarta, 1953, h. 147.

R. Tresna, Azas-Azas Hukum Pidana, PT. Tiara, Jakarta, 1959, h. 18. 
masih terus terjadi di muka bumi ini, termasuk Indonesia yang mayoritas masyarakatnya muslim. Berdasarkan permasalahan di atas, Islam menawarkan konsep penting tentang masalah kejahatan terhadap nyawa manusia, dengan menyebutkan bahwa tindak pidana pembunuhan (al-qatl) disebut dengan al-jinayah 'ala al-insaniyyah

(kejahatan terhadap jiwa manusia). Sebutan ini sama dengan penger- tian pembunuhan dalam hukum positif. Dalam al-Quran surat al-Maidah ayat 32, Allah SWT berfirman:

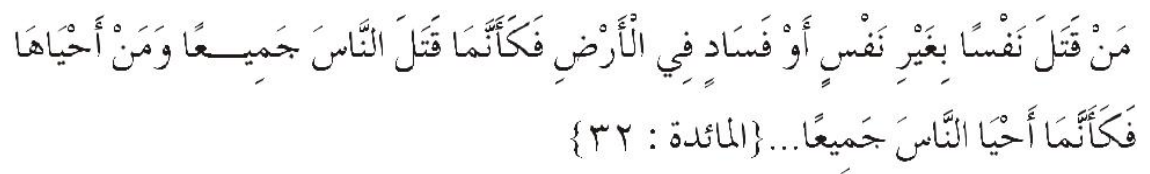

Barangsiapa yang membunuh seorang manusia, bukan karena orang itu (membunuh) orang lain, atau bukan karena membuat kerusakan di muka bumi, maka seakan-akan dia telah membunuh manusia selu- ruhnya. Dan barangsiapa yang memelihara kehidupan seorang manu- sia, maka seolah-olah dia telah memelihara kehidupan manusia semua- nya."

Berdasarkan ayat inilah pembunuhan diartikan oleh para ulama sebagai suatu perbuatan manusia yang menyebabkan hilangnya nyawa. Kemudian mazhab Maliki membagi pembunuhan menjadi dua macam: pembunuhan yang disengaja dan pembunuhan yang tak disengaja. Sedangkan para ulama Hanafiyah, Syafi'iyah, dan Hambali membagi pembunuhan menjadi tiga macam, yaitu (1) pembunuhan sengaja (qatl al-'amd), yaitu suatu perbuatan penganiayaan terhadap seseorang dengan maksud untuk menghilangkan nyawanya; (2) pembunuhan semi sengaja (qatl syibh al-'amd), yaitu perbuatan penganiayaan terhadap seseorang tidak dengan maksud untuk membunuhnya, tetapi mengakibatkan kematian, dan (3) pembunuhan karena kesalahan (qatl al-khata'), yaitu pembunuhan yang disebabkan salah dalam perbuatan, salah dalam maksud, dan karena lalai.

Dalam pandangan hukum pidana Islam, bagi orang yang membu-

Abdul Aziz Dahlan (et. al.)., Ensiklopedia Hukum Islam, PT Ichtiar Baru van Hoeve, Jakarta, 2001, h. 682.

Topo Santoso, Membumikan Hukum Pidana Islam: Penegakan Syariat dalam

Wacana dan Agenda, Gema Insani Press, Jakarta, 2003, h. 36. 
nuh tanpa sebab yang dibenarkan oleh agama akan dijatuhi sanksi pidana yang sangat berat, yakni dengan tindak pidana mati atau hukuman qishash. Namun, pelaksanaan hukuman itu diserahkan kepada putusan keluarga si terbunuh. Pilihannya, apakah tetap dilaksanakan hukuman qishash atau dimaafkan dengan penggantian berupa denda sebesar yang ditetapkan keluarga si terbunuh. Dengan demikian, dapat dipahami bahwa dalam tujuan diadakannya hukum qishash ialah untuk melindungi hak Allah atas hamba dalam masyarakat, terutama menyangkut hak hidup seseorang.

Penjalasan di atas menunjukkan bahwa setiap perbuatan hukum yang mengakibatkan hilangnya nyawa seseorang bias dikenai hukum qishash-diyat. Namun, akibat perkembangan zaman yang bergitu pe- sat, mudahnya akses hubungan internasional, cepat menyebarnya berita-berita di dunia, maka pada saat itu pula mulai banyak dari para intelektual Islam yang menjadikan materi-materi asing sebagai pendekatan dalam menentukan hukum, salah satunya melalui pende- katan sosial (termasuk di dalamnya Hak Asasi Manusia) dan maksud-maksud hukum (maqashid al-syari'ah).

Melalui pendekatan-pendekatan ini, timbullah permasalahan tentang relevansi qishash dalam Islam di era modern ini. Bagi kelompok liberal (yang banyak dipelopori oleh Jaringan Islam Liberal dan JIMM), pembahasan qishash adalah pembahasan kuno karena hal itu merupakan tradisi bangsa Arab pra-Islam yang kemudian dimasukkan ke dalam bagian hukum Islam dan bertentangan dengan maqashid alsyari'ah untuk menjaga jiwa manusia. Maka yang menjadi pertanyaan mendasar adalah: Apakah wajar jika menjaga jiwa ini diartikan seperti yang diterangkan oleh jumhur ulama, bahwa jika orang membunuh maka ia juga harus dibunuh? Di manakah bentuk penjagaan atas jiwa yang secara adil dalam hukum qishash ini? Dan apakah pengertian yang adil dalam firman Allah "kecuali yang hak (untuk dibunuh)"?

Abdurrahman Madjrie dan Fauzan al-Anshari, Qishash: Pembalasan yang Hak, Khairul Bayan, Jakarta, 2003, h. 10. 


\section{B. Pembahasan}

\section{Pengertian Qishash dalam Hukum Islam.}

Secara literal, qishash merupakan kata turunan dari qashsha-

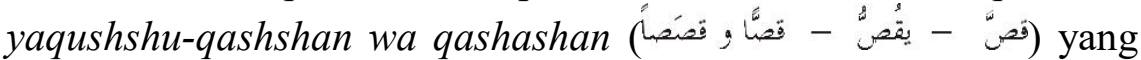
berarti menggunting, mendekati, menceritakan, mengikuti (jejaknya), dan membalas. ${ }^{10}$ Sedangkan secara istilah, Ibnu Manzur $^{11}$ di dalam kitabnya Lisan al-Arab menyebutkan,

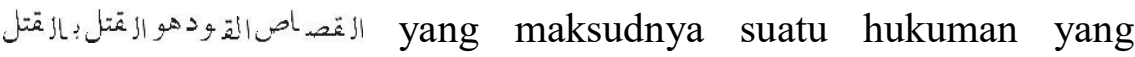
ditetapkan dengan cara mengikuti bentuk tindak pidana yang dilakukan, seperti membunuh dibalas de- ngan membunuh. Hukuman mati seperti ini disebut qishash karena hukuman ini sama dengan tindak pidana yang dilakukan yang meng- akibatkan qishash tersebut, seperti membunuh dibalas dengan mem- bunuh dan memotong kaki dibalas dengan pemotongan kaki pelaku tindak pidana tersebut.

Al-Quran sendiri memberikan isyarat bahwa yang dimaksud dengan qishash adalah sanksi hukum yang ditetapkan dengan semirip mungkin (yang relatif sama) dengan tindak pidana yang dilakukan sebelumnya. Dalam al-Quran, kata qishash disebutkan empat kali dan semuanya di dalam bentuk ism (kata benda). Dua di antaranya ism ma'rifah (kata benda definitif) dengan alif dan lam (Çá ) dan dua yang lain ism nakirah (kata benda indenfinitif). ${ }^{12}$

Imam Taqy al-Din Abi Bakr bin Muhammad al-Husaini alDamasyqy al-Syafi'i di dalam bukunya Kifayah al-Akhyar menyebutkan bahwa seseorang terkena hukum qishash karena beberapa syarat: pem- bunuh baligh, pembunuh berakal, pembunuh bukan orang kafir, dan yang dibunuh bukan budak. ${ }^{13}$

10 Ahmad Warson Munawwir, Al-Munawwir Kamus Arab-Indonesia, Pondok Pe- santren Al-Munawwir, Yogyakarta, 1984, h. 1210.

11 Ibnu Manzur, Lisan al-Arab, Bab Qaud Juz 3, CD. Al-Maktabah al-Syamilah, h. 370.

12 Sahabuddin [et al.], Ensiklopedia al-Quran: Kajian Kosakata, Lentera Hati, Ja- karta, 2007, h. 772-773.

13 Imam Taqy al-Din Abi Bakr bin Muhammad al-Husaini al-Damasyqy al-Syafi'i, Kifayah al-Akhyar fi Halli Ghayah al-Ikhtishar, Maktabah Usaha Keluarga, Se- marang, t.th., h. 159-160. 


\section{Bentuk Jarimah Qishash}

Klasifikasi kejahatan yang paling penting dan paling banyak dibahas para ahli hukum Islam adalah hudud, qishash, dan ta'zir. Kejahatan hudud adalah kejahatan yang paling serius dan berat dalam hukum pidana Islam. Ia adalah kejahatan terhadap kepentingan publik. Kejahatan dalam kategori ini dapat didefinisikan sebagai kejahatan yang diancam dengan hukuman hadd, yaitu hukuman yang ditentukan sebagai hak Allah. Dalam definisi ini, hukuman yang ditentukan, berarti bahwa baik kuantitas maupun kualitasnya ditentukan dan ia tidak mengenal tingkatan. Menurut Mohammad Ibnu Ibrahim Ibnu Jubair, yang tergolong kejahatan hudud ada tujuh kejahatan yaitu riddah (murtad), al-baghy (pemberontakan), zina, qadzaf (tuduhan palsu zina), sariqah (pencurian), hirabah (perampokan), dan shurb alkhamr (meminum khamar). ${ }^{14}$

Kategori berikutnya adalah qishash. Ia jatuh pada posisi di tengah antara kejahatan hudud dan ta'zir dalam hal beratnya. Kejahatan dalam kategori qishash ini kurang serius dibanding yang pertama (hudud), namun lebih berat dari pada yang berikutnya yakni ta'zir. Sasaran dari kejahatan ini adalah integritas tubuh manusia, sengaja atau tidak sengaja. Ia terdiri dari apa yang dikenal dalam hukum pidana modern sebagai kejahatan terhadap manusia atau crimes against persons.

Adapun menurut Abdurrahman Madjrie dan Fauzan alAnshari dalam menjelaskan tentang macam-macam qishash, ada dua macam perbuatan melanggar hukum yang bakal dikenakan hukum qishash, yakni pembunuhan yang dilakukan terhadap orang yang sebanarnya tidak layak dibunuh (pembunuhan tanpa hak), dan pencederaan ter- hadap anggota badan tanpa hak. ${ }^{15}$

Klasifikasi di atas didasarkan pada hadits nabi Muhammad Saw yang diriwayatkan oleh Aisyah RA:

14 Muhammad bin Ibrahim ibn Jubair, Criminal Law in Islam and the Muslim World: A Comparative Perspective, Institut of Objektive Studies, Delhi, 1996, h. 54-55.

15 Abdurrahman Madjrie dan Fauzan al-Anshari, op.cit., h. 19. 


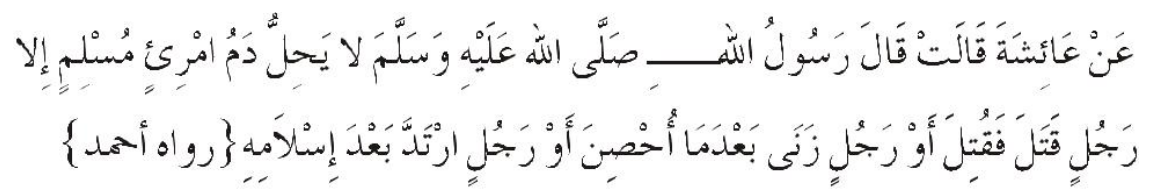

"Dari Aisyah RA berkata, Rasulullah Saw bersabda: Tidak halal darah seorang muslim (keluar) kecuali karena membunuh maka dibalas bu- nuh, seorang yang berzina muhshan, atau seorang yang murtad setelah sebelumnya ia muslim." (HR. Ahmad) ${ }^{16}$

Lebih lanjut mereka menjelaskan bahwa pembunuhan yang dapat terkena hukum qishash adalah:

a. Pembunuhan dengan sengaja, yakni pembunuhan yang langsung dilakukan kepada korbannya, seperti dengan cara menembak, me- nyembelih, memukul, dan melempar dengan panah, tombal atau alat-alat pembunuh lainnya hingga mati.

b. Beberapa orang membunuh satu orang.

c. Orang yang merdeka membunuh budak.

d. Ahli kitab membunuh wanita muslimah. ${ }^{17}$

\section{Maqashid al-Syari'ah Menurut al-Syathibi}

Islam sebagai agama samawi memiliki kitab suci al-Quran. Sebagai sumber utama, al-Quran mengandung berbagai ajaran. Di kalangan ulama ada yang membagi kandungan al-Quran kepada tiga kelompok besar, yaitu aqidah, khuluqiyyah, dan 'amaliyah. Aqidah berkaitan dengan dasar-dasar keimanan. Khuluqiyah berkaitan dengan etika atau akhlak. Amaliyah berkaitan dengan aspek-aspek hukum yang muncul dari aqwal (ungkapan-ungkapan), dan af'al (perbuatan-perbuatan manusia). Kelompok terakhir ('amaliyah) ini dalam sistematika hukum Islam dibagi ke dalam dua besar. Pertama, ibadah, yang di dalamnya diatur pola hubungan manusia dengan Tuhan. Kedua, muamalah, yang di dalamnya diatur pola hubungan antara sesama manusia. ${ }^{18}$

16 Imam Ahmad bin Hanbal, Musnad Imam Ahmad bin Hanbal Kitab Baqi Mus- nad al-Anshari Nomor Hadits 24611, CD al-Bayan.

17 Abdurrahman Madjrie dan Fauzan al-Anshari, op.cit., h. 24.

18 Abd al-Wahab Khalaf, 'Ilm Ushul al-Fiqh, Dar al-Kuwaitiyyah, Kairo, 1968, h. 
Secara lughawi (bahasa), maqashid al-syariah terdiri dari dua kata, yakni maqashid dan syariah. Maqashid adalah bentuk plural, yang ber- arti kesengajaan atau tujuan. ${ }^{19}$ Syariah secara bahasa berarti jalan me- nuju sumber air. Jalan menuju sumber air ini dapat pula dikatakan sebagai jalan ke arah sumber pokok kehidupan. ${ }^{20}$

Dalam karyanya al-Muwafaqat, al-Syathibi mempergunakan kata yang berbeda-beda berkaitan dengan maqashid al-syariah. Kata-kata itu ialah maqashid al-syariah, ${ }^{21}$ al-maqashid al $\square$ syar'iyyah fi alsyariah $^{22}$ dan maqashid min syar'i al-hukm. ${ }^{23}$ Pada hemat penulis, walau dengan kata-kata yang berbeda, mengandung pengertian yang sama yakni tu- juan hukum yang diturunkan oleh Allah SWT. Sebagaimana yang telah disampaikan oleh al-Syathibi sendiri:

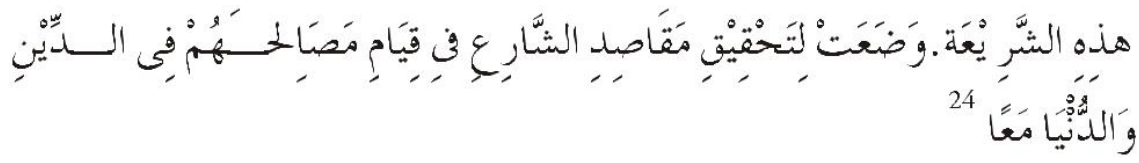

"Syari'ah ini bertujuan untuk mewujudkan kemaslahatan manusia di akhirat dan dunia bersama."

Dalam ungkapan Al-Syathibi yang lain adalah:

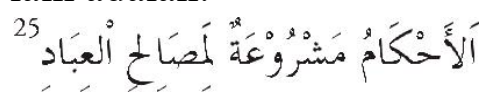

"Hukum-hukum disyariatkan untuk kemaslahatan hamba."

Apabila ditelaah pernyataan al-Syathibi tersebut, dapat dikatakan bahwa kandungan maqashid al-syari'ah atau tujuan hukum adalah kemaslahatan umat manusia. Pemahaman maqashid al-syariah mengambil porsi cukup besar dalam karya Al-Syathibi. Maqashid al-Syariah

32.

19 Hans Wehr, A Dictionary of Modern Written Arabic, Mac Donald \& Evan Ltd, London, 1980, h. 767.

20 Fazlurrahman, Islam, Pustaka, Bandung, 1984, h. 140.

21 Al-Syathibi, al-Muwafaqat fi Ushul al-Syari'ah, Dar al-Kutub al-'Ilmiyah, Beirut, 2003, Juz I, h. 15.

22 Ibid., h. 16.

23 Ibid., Juz II, h. 283.

24 Ibid., h. 3.

25 Ibid., Juz II, h. 42. 
secara tidak langsung dipaparkan hampir dalam keempat volume Al-Muwafaqat.

Pemberian porsi yang besar terhadap kajian maqashid al-syari'ah oleh al-Syathibi ini bertitik tolak dari pandangannya bahwa semua kewajiban (taklif) diciptakan dalam rangka merealisasikan kemaslahatan hamba. Tak satu pun hukum Allah dalam pandangan alSyathibi yang tidak mempunyai tujuan. Hukum yang tidak mempunyai tujuan sama dengan taklif ma la yutaq (membebankan sesuatu yang tak dapat dilaksanakan). Suatu hal yang tak mungkin terjadi pada hukum-hukum Tuhan. Dalam mengomentari pandangan al-Syathibi ini, Fathi al-Daraini memperkuatkannya. Ia mengatakan bahwa hukum-hukum itu bukanlah dibuat untuk hukum itu sendiri, melainkan dibuat untuk tujuan lain yakni kemaslahatan. ${ }^{26}$

Muhammad Abu Zahrah dalam kaitan ini menegaskan bahwa tujuan hakiki hukum Islam adalah kemaslahatan. Tak satu pun hukum yang disyariatkan baik dalam al-Quran maupun Sunnah melainkan di dalamnya terdapat kemaslahatan. ${ }^{27}$ Ajaran (doktrin) maqashid al-syariah Al-Syathibi, menurut Khalid Mas'ud, adalah upaya memantapkan maslahat sebagai unsur penting dari tujuantujuan hukum. ${ }^{28}$ Agaknya tidak berlebihan apabila dikatakan bahwa maqashid al-syariah Al-Syathibi berupaya mengekspresikan pene- kanan terhadap hubungan kandungan hukum Tuhan dengan aspirasi hukum yang manusiawi.

Namun lebih jelasnya, bagi al-Syathibi, tidak menjadi persoalan apakah Allah dalam al-Quran telah memberikan sesuatu secara terperinci atau tidak. Adapun pernyataan di dalarn al-Quran bahwa Islam telah sempurna sebagai agama untuk manusia [QS.5:3] menunjukkan bahwa al-Quran telah mencakup dasar-dasar kepercayaan dan praktek agama dengan berbagai aspek. Ini sebaliknya pula berarti bahwa tak satu pun yang berada di luar ajaran al-Quran itu. Sampai di sini

26 Fathi al-Daraini, al-Manahij al-Ushuliyah fi Ijtihad bi al-Ra'yi fi al-Tasyri', Dar al-Kitab al-Hadits, Damsyiq, 1975, h. 28.

27 Muhammad Abu Zahrah, Ushul al-Figh, diterjemahkan oleh Saefullah Ma'shum dkk., Pustaka Firdaus, Jakarta, 2005, h. 548.

28 Muhammad Khalid Mas'ud, Islamic Legal Philosophy, Islamic Research Institute, Islamabad, 1977, h. 223. 
muncul pertanyaan bagaimana posisi Sunnah? Apakah menjadi dasar konsep maqashid al-syariah? Menurut al-Syathibi, Sunnah adalah se- gala sesuatu yang diperoleh dari Nabi, yakni hal-hal yang tidak dijelas- kan dalam al-Quran. Jadi Sunnah merupakan bayan (penjelasan) ter- hadap al-Quran. Uraian hukum-hukum yang diambil dari al-Quran terlebih dahulu dicari dalam Sunnah. ${ }^{29}$

\section{Qishash dalam Maqashid al-Syariah}

Jika dilihat dari kacamata al-Syathibi, sesungguhnya qishash merupa- kan pembahasan dalam salah satu bagian maqashid alsyariah yang tiga, yakni:

1. Al-Dharuriyah

2. Al-Hajiyah

3. Al-Tahsiniyah ${ }^{30}$

Pada bagian al-dharuriyah, sesungguhnya pembahasan qishash berada dalam penjelasan menjaga jiwa, di mana al-Syathibi menjelaskan:

31

بحموع الضروريات خمسة وهي حفظ الثدين والنفس والنسل والمال والعقل

"Cakupan bahasan al-dhaririyat ada lima, yakni menjaga agama, jiwa, keturunan, harta, dan akal."

Sebelum menyampaikan kata-kata di atas, al-Syathibi menyebut- kan:

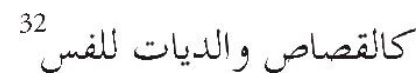

"Seperti qishash dan diyat (yang masuk dalam pembahasan menjaga) jiwa."

Pada halaman yang lain ia menyebutkan bahwa:

29 Al-Syathibi, op.cit., Juz III, hlm. 241-242.

30 Al-Syathibi, op.cit., Juz II, hlm. 7

31 Ibid., hlm. 8.

32 Ibid. 


$$
\text { فنحو التماثل فن القصاص فإنه لا تدعو إليه ضرورة و لا تظهر فيه شدة حاجة و }
$$

"Maka mengenai hal-hal yang serupa dengan qishash maka ia tidak termasuk dalam hal yang dharuri (primer), tidak tampak yang menguatkkannya masuk dalam hal yang hajy (skunder), akan tetapi ia hanya sebagai pelengkap (tersier)."

Syekh Abdullah Darraz dalam mensyarah kata-kata di atas dengan menyebutkan:

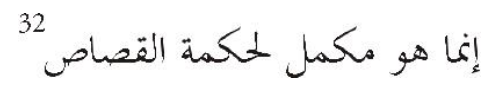

"Sesungguhnya hal itu merupakan pelengkap dari adanya hikmah qishash."

Hikmah-hikmah tersebut berasal dari firman Allah SWT:

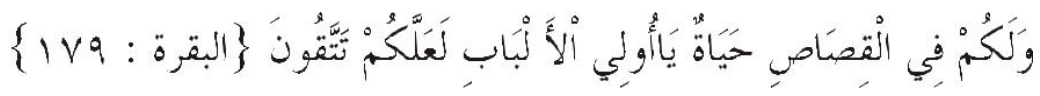

"Dan dalam qishash itu ada (jaminan kelangsungan) hidup bagimu, wahai orang-orang yang berakal, supaya kamu bertakwa." (QS. Al-Baqarah: 179). ${ }^{34}$

Juga atas perintah Allah untuk menghormati nyawa manusia:

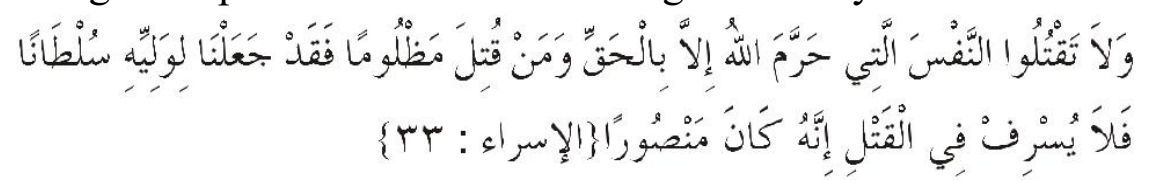

"Dan janganlah kamu membunuh jiwa yang diharamkan Allah (membunuhnya), melainkan dengan suatu (alasan) yang benar. Dan barang- siapa dibunuh secara zalim, maka sesungguhnya Kami telah memberi kekuasaan kepada ahli warisnya, tetapi janganlah ahli waris itu melam- paui batas dalam membunuh. Sesungguhnya ia adalah orang yang men- dapat pertolongan." (QS. Al-Isra': 33). ${ }^{35}$

33 Ibid.

34 Departemen Agama RI, op.cit., h. 53.

35 Ibid., h. 429. 
Dan hadits Rasulullah Saw yang menyatakan bahwa:

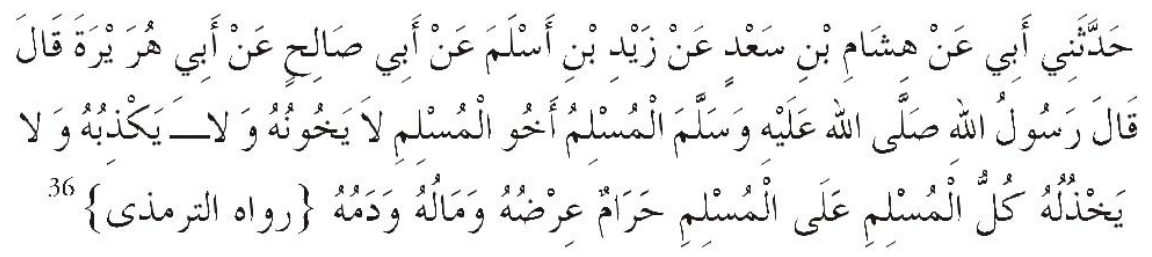

"Disampaikan kepadaku oleh ayahku dari Hisyam bin Sa'ad dari Zaid bin Aslam dari Abu Shaleh dari Abu Hurairah berkata, Rasulullah Saw bersabda: seorang muslim dengan muslim lainnya bersaudara maka janganlah mengkhianatinya, jangan menipunya, dan jangan meninggalkannya. Setiap muslim dengan muslim lainnya itu haram (terjaga) kehormatannya, hartanya, dan darahnya." (HR. Al-Turmudzi).

Adapun dalam memahami maksud di atas, pengejewantahannya melalui tiga cara:

1. Melakukan analisis terhadap lafal perintah dan larangan.

2. Penelaahan 'illah al-amr (perintah) dan al-nahyu (larangan).

3. Analisis terhadap al-sukut 'an syar'iyyah al-'amal ma'a qiyam al-ma'na Al-muqtadhalah (sikap diam al-syari' dari pensyaratan se- suatu).

Berdasarkan ketiga cara di atas, maka sesungguhnya pembahasan hukum qishash dalam Islam merupakan bagian yang dikaji melalui "penelaahan 'illah al-amr (perintah) dan al-nahyu (larangan)". Salah satu perintah tentang pelaksanaan hukum qishash ini berasal dari firman Allah SWT dalam al-Quran Surat Al-Baqarah ayat 178-179 dan hadits Nabi Muhammad Saw yang diriwayatkan oleh al-Turmudzi, dan lain-lain, sebagaimana yang telah penulis paparkan sebelumnya.

Adapun 'illah suatu hukum adakalanya tertulis secara jelas dan ada- kalanya tidak tertulis secara jelas. Apabila 'illah itu tertulis secara jelas di dalam ayat atau hadits, maka menurut al-Syathibi harus mengikuti apa yang tertulis itu. Karena dengan mengikuti yang tertulis tersebut, tujuan hukum dalam perintah dan larangan itu dapat dicapai.

36 Imam al-Turmudzi, Sunan al-Turmudzi, Kitab al-Bir wa al-Shillah, Nomor Ha- dits 1850, CD. Al-Bayan. 
Hal ini menunjukkan bahwa qishash merupakan bagian dari 'illah yang telah tertulis secara jelas dalam al-Quran Surat al-Baqarah ayat 179 yakni "Dan dalam qishaash itu ada (jaminan kelangsungan) hidup bagimu, hai orang-orang yang berakal, supaya kamu bertakwa." Dengan demikian artinya, qishash itu jika dilaksanakan maka akan menjamin kelangsungan hidup setiap manusia.

Sepintas, hukum qishash nampak kejam, tidak manusiawi, primitif, barbar, atau ketinggalan zaman, bahkan melanggar HAM (Hak Asasi Manusia). Menurut Teaching Human Rights yang diterbitkan oleh Perserikatan Bangsa-Bangsa (PBB), Hak Asasi Manusia adalah hak-hak yang melekat pada diri setiap manusia, yang tanpanya manusia mustahil dapat hidup sebagai manusia. Hak hidup misalnya, adalah klaim untuk memperoleh dan melakukan segala sesuatu yang dapat membuat seseorang tetap hidup, karena tanpa hak tersebut eksistensi- nya sebagai manusia akan hilang.

Memang, qishash merupakan hukuman yang kejam, namun hal ini terjadi karena pelaku pembunuhan juga kejam, bahkan sangat kejam. Seseorang dianggap melenggar HAM ketika hukum qishash akan dijalankan, namun orang yang telah membunuh orang lain ti- dak terkena hukum HAM. Lihatlah, karena ambruknya wibawa dan penegakan hukum, nyawa manusia menjadi sangat murah. Bila keja- hatan ini terus dibiarkan, eksistensi kehidupan manusia akan teran- cam.

Kekejaman memang harus dihentikan dengan hukuman yang setimpal agar bisa menjerakan (deterensif). Dengan qishash, pelaku sebelum berbuat jahat akan pikir-pikir dulu, karena korban atau ahli warisnya (bila korban meninggal) berhak membalas dengan perlakuan setimpal. Sebagai contoh adalah hukum qishash di tanah haram Makkah al-Mukarramah. Ada jamaah yang menunaikan ibadah haji dan kala itu mereka cekcok dengan sopir taksi yang mengangkut mereka lantaran dia memungut ongkos melebihi tarif semestinya. Sopir itu menahan barang mereka sampai mereka mau membayar sesuai keinginannya. Mereka menolak. Sopir itu makin marah, matanya melotot dan tangannya menggoyang-goyang. Anehnya, meski berbadan lebih besar, ia tidak sampai memukul atau melukai mereka. 
Datanglah seorang polisi melerai mereka. Akhirnya, ia menegur sopir tadi dan mereka pun dibebaskan. Mereka sempat bertanya kepada polisi, "Bagaimana kalau sopir tadi memukul kami?". Jawab polisi: "Kalau begitu, dia akan dikenai hukuman qishash (balas pukul), di- denda, atau dimaafkan. Hukuman itu tergantung pada pilihan Anda atau ahli waris Anda". Mendengar uraian tersebut, mereka berujar, "Duhai andaikata hukum qishash diterapkan di negeri kami, niscaya orang akan berpikir tujuh kali sebelum memukul, melukai, atau mem- bunuh orang lain”.

Sekali lagi penulis tegaskan, bagi sebagian orang, jenis hukuman ini dinilai tidak manusiawi, primitif, barbar, atau ketinggalan zaman, bahkan melanggar HAM. Karena itu, orang-orang yang telah menjadi korban penyesatan opini semacam ini menjadi benci terhadap hukum Islam lalu memilih hukum lain (hukum positif). Padahal, penyakit sosial yang bernama pembunuhan hanya akan efektif dicegah dengan obat yang telah disediakan oleh yang menciptakan nyawa manusia, yaitu dengan qishash.

Dengan hilangnya wibawa hukum, akhirnya Rian (sang penjagal dari Jombang) mampu dan begitu tega untuk membunuh bahkan memutilasi manusia lebih dari 11 orang. Bahkan untuk tahun 2008 saja (data terakhir dari Metro TV sampai bulan September) tercatat bahwa pembunuhan yang disertai dengan mutilasi mencapai 28 korban. Hal ini terjadi karena penjara bukanlah obat mujarab bagi para pembunuh. Pasalnya, seringkali terjadi seorang pembunuh "kelas teri" tiba-tiba berubah menjadi pembunuh "kelas kakap" justru setelah keluar dan penjara. Karena, selama di penjara rupanya ia sering berinteraksi dengan pembunuh lainnya yang lebih profesional. Dia pun "belajar" kepada para seniornya itu. Lebih miris lagi adalah bahwa pada Pasal 338 KUHP (Kitab Undang-undang Hukum Pidana) Buku II Titel XIX disebutkan, barangsiapa yang dengan sengaja menghilangkan jiwa orang, karena pembunuhan biasa, dihukum dengan hukuman penjara selama-lamanya lima belas tahun. (CP. 295, $299 \mathrm{v}$ ).

Di samping itu, negara juga berkewajiban menghidupi mereka selama dalam tahanan. Adapun biaya yang hars dikeluarkan negara untuk memberi makan para napi jelas memberatkan kas negara, bahkan 
jika dialokasikan kepada masyarakat tidak mampu akan lebih berguna. Sebagai contoh, biaya makan setiap napi per hari adalah Rp 3.500,-. Jadi selama dipenjara, misalnya 15 tahun sebagai hukum maksimal bagi pembunuh, maka negara harus mengeluarkan dana makan saja sebesar 15 x 365 x Rp 3.500,- = Rp 19.162.500,- Belum lagi biaya kesehatan, pakaian, dan sebagainya. Padahal, dia telah terbukti melakukan kejahatan dengan membunuh. Jadi, logiskah orang-orang yang di luar penjara harus memberi makan (lewat pembayaran pajak yang kemudian diolah menjadi APBN dan APBD) para pembunuh yang dipenjara yang berkemungkinan akan mengulangi kejahatannya karena psikologinya telah terganggu?

Obat memang harus diberikan sesuai dengan penyakit yang diderita berdasarkan hasil diagnosis yang akurat. Karena itu, Allah SWT telah menyediakan obat mujarab untuk menanggulangi bentuk kejahatan terhadap manusia melalui qishash. Sebaliknya, bila manusia mengambil obat selainnya, maka dimungkinkan penyakit masyarakat tersebut akan muncul kembali atau kian parah. Oleh karena itu, jika dilihat dari aspek penegakan hukum, maka sebenarnya ada dua aspek penegakan hukum yang harus memenuhi asas ini:

1. Keadilan bagi korban penyelewengan hukum, keadilan bagi masya- rakat.

Dalam hal ini, qishash merupakan mekanisme hukum dalam mencari keadilan yang diberikan Allah SWT bagi manusia yang dirugikan dalam kasus pelanggaran hukum. Tanpa penegakan me- kanisme ini, wajar saja hukum positif yang ada belum mampu memberikan efek keadilan bagi si korban.

2. Aspek kedua adalah efek jera bagi manusia lain.

Pelaksanaan hukum qishash akan menjadi pelajaran berharga bagi orang lain, yaitu menimbulkan rasa takut kepada setiap orang sehingga tidak berani melakukan kejahatan serupa. Mereka akan berpikir ribuan kali lipat sebelum melakukan pembunuhan atau pencederaan. Qishash, bila diterapkan, akan menjadi piranti efektif untuk menumbuhkan efek jera di kalangan masyarakat. 
Berdasarkan penjelasan di atas, terlihat sekali apa yang dinamakan adil oleh al-Syathibi, yakni kemashlahatan yang terbagi ke dalam dua hal: Al-Mashalih al-Dunyawiayah (tujuan kemaslahatan dunia), dan Al-Mashalih al-Ukhrawiyah (tujuan kemaslahatan akhirat). Kedua pembagian ini menunjukkan muatan dan skala prioritas dalam pengembangan hukum. Lebih dalam lagi dari kajian qishash mealui 'illah hukum adalah bahwa 'illah itu sesungguhnya mengandung arti yang sangat luas yakni kemaslahatan-kemaslahatan dan hikmahhikmah yang berkaitan dengan, al-Awamir (perintah-perintah), alIbahah (kebolehan), dan al-Mafasid (kemafsadatan) yang berkaitan dengan al-Nawahi (larangan-larangan).

'Illah qishash dalam hal ini telah tertulis secara jelas dalam al-Quran Surat al-Baqarah ayat 179:

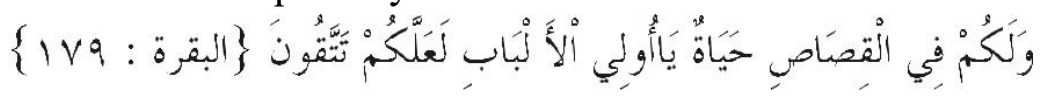

"Dan dalam qishaash itu ada (jaminan kelangsungan) hidup

bagimu, hai orang-orang yang berakal, supaya kamu bertakwa."

Dari ayat ini bisa dilihat bahwa qishash merupakan akibat dari kejahatan terhadap manusia dan 'illah-nya ialah untuk menjamin kelangsungan hidup manusia. Dengan demikian, jika qishash dilaksanakan maka kelangsungan hidup manusia di dunia akan terjamin.

Lebih jelasnya lagi ialah bahwa yang menjadi tujuan hukum (ma- qashid al-syari'ah) menurut al-Syathibi, sebagaimana yang diuraikan panjang lebar dalam kitab Al-Muwafaqat, bukan untuk membalas bunuh bagi orang yang membunuh, melainkan ayat tentang qishash tadi bertujuan untuk mewujudkan kelangsungan hidup, keamanan, keadilan, dan ketenteraman dalam masyarakat.

Al-Syathibi menyampaikan:

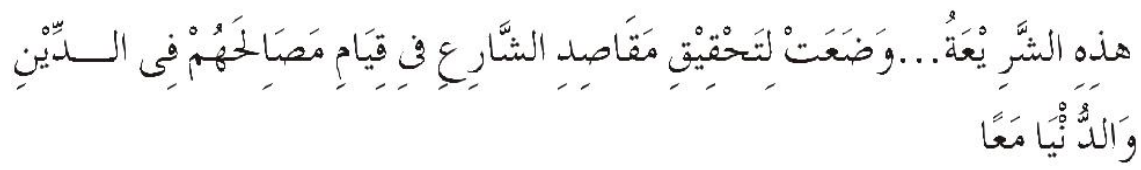

"Syari'ah ini... bertujuan untuk mewujudkan kemaslahatan manusia di akherat dan dunia bersama." 
Dalam ungkapan Al-Syathibi yang lain adalah:

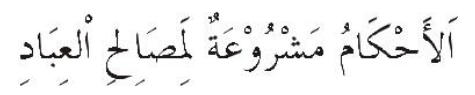

"Hukum-hukum disyari'atkan untuk kemaslahatan hamba."

Dengan demikian, qishash dalam hukum pidana Islam merupakan hukum yang sempurna untuk diterapkan, karena ia dapat membawa kemaslahatan bagi seluruh umat manusia, dan sesuai dengan firman Allah SWT: "Tidaklah Kami (Allah) mengutus engkau (Muhammad) kecuali untuk membawa rahmat bagi seluruh alam."

Pada akhirnya dapat ditarik garis merah bahwa konsep maqashid al-syari'ah al-Syathibi sangat penting artinya dalam mengembangkan metode-metode ijtihad yang pernah dikemukakan oleh ulama-ulama ushul fikih baik dalam dalam metode ijtihad bercorak ta'lili maupun metode ijtihad yang bercorak istishlahi, sekaligus sebagai sarana pembentukan hukum Islam era ini. Penekanan pada pertimbangan maqashid al-syari'ah dapat menjadikan hukum Islam lebih mampu memberikan jawaban permasalahan-permasalahan yang timbul. Kecuali itu, pertimbangan maqashid al-syari'ah bisa disebut sebagai pen- dekatan filsafat hukum dalam Islam.

\section{Kesimpulan}

1. Dalam hukum pidana Islam, qishash merupakan pilihan hukuman pertama bagi orang yang melakukan kejahatan terhadap tubuh ma- nusia, kemudian diyat (damai dengan denda) atau dengan cara memaafkan. Hal ini dilakukan oleh keluarga atau ahli waris dari sang korban.

2. Maqashid al-Syari'ah menjelaskan bahwa qishash dalam al-Quran merupakan akibat hukum dari kejahatan terhadap manusia dan 'illah-nya ialah untuk menjamin kelangsungan hidup manusia. Dengan demikian, jika qishash itu dilaksanakan maka kelangsungan hidup manusia, keamanan, keadilan, dan ketenteraman dalam masyarakat di dunia akan terjamin. 


\section{DAFTAR PUSTAKA}

Abdul Aziz Dahlan (et al.), Ensiklopedia Hukum Islam, PT Ichtiar Baru van Hoeve, Jakarta, 2001.

Abdul Rozak dkk (ed), Pendidikan Kewargaan Civic Education:

Demo- krasi Hak Asasi Manusia dan Masyarakat Madani, ICCE UIN Syarif Hidayatullah, Jakarta, 2003.

Abd al-Wahab Khalaf, 'Ilm Ushul al-Fiqh, Dar al-Kuwaitiyyah, Kairo, 1968.

Abdurrahman Madjrie dan Fauzan al-Anshari, Qishash: Pembalasan yang Hak, Khairul Bayan, Jakarta, 2003.

Ahmad Warson Munawwir, Al-Munawwir Kamus Arab-Indonesia, Pon- dok Pesantren Al-Munawwir, Yogyakarta, 1984.

A. Ubaedillah dkk, Demokrasi Hak Asasi Manusia dan Masyarakat Ma- dani, ICCE UIN Syarif Hadayatulah, Jakarta, 2006.

Al-Syathibi, al-Muwafaqat fi Ushul al-Syari'ah, Dar al-Kutub al'Ilmiyah, Beirut, 2003.

Moeljatno, Azas-Azas Hukum Pidana, tp, Yogyakarta, 1980.

Dali Mutiara Djaksa Kepala Jakarta, Kitab Undang-Undang Hukum Pi-dana Republik Indonesia, Cet. IV, Suar, Djakarta, 1953.

Fazlur Rahman, Islam, Pustaka, Bandung, 1984.

Fathi al-Daraini, Al-Manahij al-Ushuliyah fi Ijtihad bi al-Ra 'yi fi al-

Tasyri', Dar al-Kitab al-Hadits, Damsyiq, 1975.

Hans Wehr, A Dictionary of Modern Written Arabic, Mac Donald \& Evan Ltd, London, 1980.

Ibnu Manzur, Lisan al-Arab, Bab Qaud Juz 3, CD. Al-Maktabah alSyamilah.

Imam Ahmad bin Hanbal, Musnad Imam Ahmad bin Hanbal Kitab Baqi Musnad al-Anshari Nomor Hadits 24611, CD al-Bayan.

Imam al-Turmudzi, Sunan al-Turmudzi, Kitab al-Bir wa al-Shillah, No- mor Hadits 1850, CD. Al-Bayan.

Imam Taqy al-Din Abi Bakr bin Muhammad al-Husaini al-Damasyqy 
al-Syafi'i, Kifayah al-Akhyar fi Halli Ghayah al-Ikhtishar, Maktabah Usaha Keluarga, Semarang, t.th.

Muhammad bin Ibrahim ibn Jubair, Criminal Law in Islam and the Mus- lim World: A Comparative Perspective, Institute of Objektive Studies, Delhi, 1996.

Muhammad Abu Zahrah, Ushul al-Fiqh, diterjemahkan oleh Saefullah Ma'shum dkk., Pustaka Firdaus, Jakarta, 2005.

Muhammad Khalid Mas'ud, Islamic Legal Philosophy, Islamic Research Institut, Islamabad, 1977.

R. Tresna, Azas-Azas Hukum Pidana, PT. Tiara, Jakarta, 1959.

Sahabuddin [et al.]., Ensiklopedia al-Quran: Kajian Kosakata, Lentera Hati, Jakarta, 2007.

Topo Santoso, Membumikan Hukum Pidana Islam: Penegakan Syariat da- lam Wacana dan Agenda, Gema Insani Press, Jakarta, 2003. 